\title{
Las tácticas del habitar. Prácticas de recuerdos y (re)significación de lugares en contextos de retorno de población
}

\author{
María Angélica Garzón Martínez \\ Bogotá: Colección CES. Universidad Nacional de Colombia. \\ 2019. 220 p. \\ Juliana Campuzano Botero \\ Universidad Lusófona (Portugal), Instituto Colombiano de Antropología e \\ Historia ICANH y Universidad Externado de Colombia, Bogotá, Colombia. \\ $\square$ juliana.campuzano@uexternado.edu.co \\ (1) ORCID: 0000-0003-2705-0887 \\ $\triangle$ Google Scholar
}

"Regresar a mi pueblo, por el camino viejo, recoger mis pasos empezar de nuevo [...]. Regresar a la casa, como regresa el viento, empezar de nuevo, empezar de nuevo" (Carlos Vives, "La foto de los dos") una canción que acompaña el andar de este libro y que acompañó a la autora en su trabajo de campo por tres corregimientos de los Montes de María. Una melodía que evoca el volver y en este caso el proceso del retorno visto desde lo humano.

Los Montes de María son una pequeña cadena montañosa en medio del Caribe colombiano, limitan por le este con el río Magdalena, por el oeste con el mar Caribe y conecta en dirección norte-sur la costa Caribe con el interior del país. Su ubicación estratégica como corredor económico ha sido su mayor adversidad y la disputa histórica por el control territorial ha provocado unos altos índices de violencia. Específicamente esta investigación se centra en el proceso de retorno de los corregimientos de El Salado y Macayepo, municipio del Carmen de Bolívar, y de San José del Peñón, municipio de San Juan Nepomuceno. Tres poblaciones de los Montes de 
María que sufrieron desplazamiento forzado entre los años 2000 y 2002 por los hechos de violencia perpetuados por grupos paramilitares.

María Angelica Garzón, socióloga, maestra en sociología y Doctora en Ciencias Humanas de la Universidad Nacional, es la autora de este libro. Vivió y trabajó durante varios años en los Montes de María, hecho que la llevaron a conocer de cerca sus gentes, sus cuentos, a deslumbrarse por el verde de sus montañas en invierno y los cafés en verano, a agradecer un aguacero en sequía y a ver en sus pobladores un tesón admirable. Yo Juliana Campuzano, arqueóloga y quien escribe esta reseña no puedo ser objetiva en este ejercicio. Lo menos que tendrán los lectores será un critica académica del libro de María Angélica, el amor que le tengo a esa misma tierra hizo que encontrara en este texto mis propios recuerdos al llevarme a transitar por paisajes conocidos, al remover dolores que siento en lo profundo del corazón, al traer imágenes vividas y desgarradoras de corregimientos abandonados y de casas enmontadas y al recordar las memorias de grandes amigos montemarianos que han sido desplazados y retornados. Las dos hemos recorrido y vivido esas pequeñas montañas del Caribe y estoy segura de que allí cambiamos como personas y como profesionales.

Me tomo la libertad de escribir esta reseña en primera persona como réplica consonante a la manera en que está escrita la investigación. Una apuesta osada para un texto académico, pero que responde a un posición política y personal de la autora en cuanto a su papel como investigadora. Dentro de la lectura ella constantemente pone de manifiesto sus vivencias, pensamiento y sentimientos como mujer, socióloga, madre y rola (no cachaca). Trata cada imagen y testimonio de los sujetos entrevistados con el valor y respeto que merecen las vivencias y memorias de quienes como lo dice "(...) abrieron sus puertas para que fuera posible esta investigación" (p. 13) y son las que soportan las profundas y valiosas reflexiones académicas que se plantean en el libro.

Metodológicamente y mediante un acercamiento de carácter etnográfico basado en la observación y la entrevista con personas retornadas, la autora se instala al lado del doliente, en sus palabras privilegia los principios de trabajo de memoria en los que se priorizan las voces, sentires y significados del pasado. El análisis de las narrativas del proceso del retorno será la estrategia metodológica fundamental para la construcción de esta investigación. Dicho análisis contiene tanto los contenidos de los relatos como las representaciones fundamentadas en la narración, es decir tener muy presente "Qué se cuenta, para qué se cuenta, en qué se hace énfasis, cómo se construye la trama narrativa y cómo se significa la 
experiencia narrada" (p. 98). Elementos que enriquecen profundamente la lectura de este libro. A lo largo del texto se encuentran múltiples entrevistas descritas con delicadeza y ricas en detalles que permiten acercarse a los relatos de las personas desde la sensibilidad literaria, para el análisis cada detalle toma sentido y se convierten en elementos relevantes. Los silencios, la emociones de los entrevistados y el entrevistador, el escenario y las risas, se conjugan con la literatura académica, algunas veces en un dialogo amigable y otras tantas como una bofetada a lo escrito hasta ahora sobre el retorno.

El libro esta divido en cinco capítulos, una introducción y las reflexiones finales. Inicia con una imagen de ella sentada un jeep rumbo al Salado, es imposible no sentirse en ese lugar, recordé mi primera visita al Salado y la impotencia que me generó. Logré entender sus preguntas y dimensionar la importancia de un cambio de perspectiva en relacion con el estudio de los procesos de retorno. La propuesta de esta investigadora se centra en entender el retorno no como punto final del desplazamiento sino como un proceso social, la autora propone "(...) acercarse al retorno desde su cotidianidad y mediante las practicas que utiliza la población para reconstruir y reconstruirse. En pocas palabras el retorno como un habitar" (p. 23), una propuesta novedosa dentro de la literatura académica la cual plantea de manera generalizada el retorno como el final del ciclo del desplazamiento forzado y desconoce las tácticas del habitar de los hombres y mujeres retornadas.

El primer capítulo presenta el estado del arte en la que se ha nombrado el retorno y se ha descrito o imaginado al sujeto retornado. Se analizan las distintas perspectivas tradicionales delineadas por la literatura académica y por los organismos internacionales (como fórmula de movilidad, como relacion entre deberes y derechos, y como proyecto de desarrollo). Este apartado a su vez muestra la distancia que existe entre lo escrito y lo vivido por el sujeto retornante. A medida que leía este capítulo, recordaba mi primera visita a Macayepo, iba en una camioneta de la Infantería de Marina para hacer un proyecto de arqueología para una carretera que aún no funciona, "la troncal de los Montes de María". El retorno como fórmula de movilidad y proyecto de desarrollo se materializaba en esta escena, el acompañamiento militar, el desarrollo económico y la adecuación de infraestructura como garantía de retorno y de cumplimiento de los acuerdos y derechos para población estaban ahí presentes, pero $¿ y$ los habitantes de Macayepo? Ellos seguían cruzando el arroyo 7 veces para poder salir a troncal e ir a la escuela porque la carretera no tenía puentes (ni los tiene), la luz aún no había llegado, la iglesia seguía abandonada y el miedo, así hubiera presencia militar, se sentía en 
el ambiente. Este capítulo pone en contraste en todo momento lo escrito y lo vivido, y evidencia nuevamente la necesidad de pensar el retorno desde otra perspectiva.

El segundo capítulo nos sitúa en los Montes de María, analiza su contexto geográfico e histórico, las luchas campesinas, los procesos organizativos y la violencia estructural que ha azotado a este territorio desde hace muchos años. Expone los múltiples factores que se entrelazaron en el conflicto armado reciente y explica cada uno de los procesos de desplazamiento y retorno de los tres corregimientos de estudio. Al final salta la pregunta si están dadas las condiciones para retornar, pero otra vez nos encontramos con lucha por la tenencia de tierra. Mientras María Angelica recorría los Montes de María pensando sobre el retorno, los cachacos, por eso su insistencia en que la llamaran rola, comparaban masivamente tierra para la siembra de palma, eucalipto, explotación de hidrocarburos o de material de cantera ¿Cómo retornar sin tierra?

El tercer capítulo, las narrativas del retorno, permite entender el retorno como un proceso y no como el final del camino, en las voces de los hombres y mujeres retornados se descubre como mediante la narrativa se construyen los "cimientos" para el proceso de reconstrucción personal y colectivo. En este capítulo se identifican "(...) los hitos y relatos a partir de los cuales se construyen las narrativas del retorno" (p.98), se exploran dichas narrativas y se analiza el papel que juega el recuerdo en el proceso de retornar. ¿Si estamos hablando del retorno será que hay cabida para narrar el desplazamiento? Personalmente me hizo un poco de gracia cuando al inicio de este capítulo la autora menciona que le llamó la atención que sus entrevistados iniciaran sus relatos por la narración del desplazamiento. Me sentí muy identificada, recuerdo estar en talleres con la población para la construcción del Museo Comunitario de San Jacinto hablando sobre la gaita y nunca sabia como los relatos llegaban al desplazamiento. Obviamente entendía la importancia del hecho del desplazamiento, pero fue hasta la lectura de este texto que logré dimensionar el valor de la narrativa de los hechos de violencia como un acto que busca satisfacer un deseo de justicia por parte de las victimas (p. 101).

Tomar la decisión de retornar es todo un reto, la organización de la población para enfrentarse a ese camino de regreso, llegar por entre medio de esos caminos sucios, encontrar las casas enmontadas, ver que el lugar que se dejó no está igual al regreso y sentir el abandono e incumpliendo sistemático del estado son algunos de elementos narrados a lo largo de este apartado desde la voz de las entrevistas de los hombres y mujeres retornadas. Puntos que le permitieron a la autora significar el 
retorno desde tres aristas: la emoción de volver, la ruptura y el retorno como proyecto de construcción y resistencia.

Lugares y recuerdos, se titula el cuarto capítulo, este nuevamente inicia con la imagen de María Angelica en jeep rumbo a San José del Peñón, en esta sección ella nos lleva a lo más profundo de sus entrevistas, deja ver los que piensa y lo que siente. Nos muestra imágenes recopiladas a lo largo del trabajo de campo. Aquí la investigadora entrelaza cuidadosamente las entrevistas realizadas en los tres corregimientos para construir una narrativa del retorno en la cual la cotidianidad, los recuerdos, la maternidad, la casa y la cocina se configuran en elementos detonantes de conversaciones profundas que dejan ver el lado humano del retorno.

El capítulo de las tácticas del habitar cierra este libro, se entiende como tácticas a "(...) las formas mediante las cuales los actores sociales toman parte de una realidad para controvertirla, amoldarla y hacerla útil" (p.173). A partir de tres elementos en donde la cotidianidad es el eje central, María Angelica construye un análisis novedoso para el acercamiento a los procesos de retorno de población. Desde allí se estructuran cuatro tácticas del habitar: recordar, narrar(se), organizar(se) y habitar mediante el recuerdo. Estas son estrategias que permiten no solo retornar sino permanecer en el lugar. "Las tácticas del habitar resultan en insumos, cimientos escenarios y razones que llenan de contenidos, orientan y permiten el desarrollo del proceso de retorno" (p. 201).

La última imagen que nos regala la autora es nuevamente sentada en jeep en el camino de regreso, su regreso. Este libro es un viaje reflexivo de ida y vuelta para entender y valorar el retorno como un proceso y no como un punto final al desplazamiento. Sin embargo, mientras no existan las condiciones sociales, políticas, económicas y de seguridad para poder retornar, pero sobre todo para poder habitar los lugares a los que se regresa, seguiremos viviendo en un país en el cual el desplazamiento forzado está a la orden del día, y donde el abandono de corregimientos como El saldo, Macayepo o San José del Peñón no serán eventos aislados sino el común denominador de área rural de este país.

\section{Referencias bibliográficas}

Garzón Martínez, M. A. (2019). Las tácticas del habitar. Prácticas de recuerdos y (re)significación de lugares en contextos de retorno de población. Colección CES, Universidad Nacional de Colombia. 